\title{
KESULITAN GURU PADA PEMBELARAN BIOLOGI TINGKAT MADRASAH/SEKOLAH DI PROVINSI JAWA BARAT (Studi Kasus wilayah Priangan Timur)
}

\author{
Iwan Ridwan Yusup \\ Program Studi Pendidikan Biologi, UIN Sunan Gunung Djati Bandung; \\ iwanyusup@uinsgd.ac.id mailto:bambangsbli@yahoo.com
}

\begin{abstract}
Abstrak. Penelitian ini bertujuan untuk menganalisis kesulitan yang dihadapi guru dalam pelaksanaan pembelajaran biologi pada Madrasah/Sekolah tingkatan menengah di Provinsi Jawa Barat (study Kasus Priyangan), Penelitian ini menggunakan metode penelitian kualitatif, metode pengumpulan data menggunakan observasi, wawancara, dan dokumentasi. Prosedur analisis data adalah pengumpulan data, reduksi data, penyajian data, dan penarikan kesimpulan. Diperoleh data bahwa kesulitan guru dalam pembelajaran Biologi terbagi menjadi dua; 1). Internal, pada kompetensi professional terdapat 6 materi yang dianggap sulit oleh pendidik maupun siswa yaitu sistem klasifikasi makhluk hidup 22\%, metabolisme $20 \%$, system regulasi $17 \%$, heredias dan genetik 16\%, animalia 13\%, dan Sel 12\%; kompetensi pedagogic, guru menggunakan 18 metode pembelajaran dengan dominasi $21 \%$ ceramah, $15 \%$ Praktikum, dan $21 \%$ diskusi, sisanya bervariasi, namun dalam penggunaan media $85 \%$ sudah berbasis media elektronik dan $15 \%$ masih tradisional. 2). Eksternal, yaitu tidak sesuainya kurikulum yang diberlakukan pada madrasah/sekolah dengan fasilitas kelas dan Laboratorium, kebijakan madrasah yang berbeda-beda, beragamnya peningkatan kompetensi yang telah diikuti guru biologi. Adapun persentase kesulitan dalam pemelajaran Biologi secara umum ditemui $48 \%$ dari sudut pandang siswa, $10 \%$ Guru, dan $41 \%$ sarana dan prasarana. Hasil analisis data diharapkan dapat menjadi referensi dasar dalam penetapan kebijakan dan usaha peningkatan SDM maupun Output pada madrasah/sekolah kementerian terkait.
\end{abstract}

Kata Kunci: $\quad$ Kesulitan Guru, Madrasah/sekolah, Pembelajaran Biologi.

\footnotetext{
Abstract. The Aim of this study is to analyze teachers difficulties in implementing biology learning in Madrasah / Secondary Schools in West Java Province (Case Study in Priyangan). This study was used qualitative research methods, through observation, interviews, and documentation. Data analysis procedures were data collection, reduction, presentation, and conclusion. Based on this research, teacher difficulties in Biology learning are divided into two; 1). Internally, there are 6 competencies in professional competence that are considered difficult by educators and students, namely the classification system of living things $22 \%$, metabolism $20 \%$, the regulatory system $17 \%$, heredity and genetics $16 \%$, animalia $13 \%$, and cells $12 \%$; pedagogic competence, the teacher used 18 learning methods with $21 \%$ lecturing, $15 \%$ practicum, $21 \%$ discussion, and the rest was varies, but $85 \%$ of media used was electronic media and $15 \%$ was traditional. 2). Externally, namely the incompatibility of the curriculum applied in madrasah / schools with classroom and laboratory facilities, different madrasah policies, various biology teacher competency. The percentage of difficulties in Biology learning that came from
} 
students was $48 \%$, while from teachers was $10 \%$, and $41 \%$ was from the facilities and infrastructure. The results of the data analysis are expected to be a basic reference in the determination of policies and efforts to increase human resources and output in madrasah / schools of relevant ministries.

Keywords: Teachers Difficulties, Madrasahs / Schools, Learning Biology. 


\section{PENDAHULUAN}

Pemerintah senantiasa menjaga kualitas proses dan hasil pada tiap lembaga pendidikan melalui berbagai kebijakannya. Bagi guru yang bernaung di bawah kementerian Pendidikan dan Kebudayaan (Kemendikbud) dan kementerian Agama (Kemenag) dilaksanakan sertifikasi, pembinaan MGMP/KKM, PLPG, Diklat, dan sebagainya. Kampus-kampus penyelenggara fakultas keguruan, diakreditasi secara berkala untuk menjaga kualitas lulusan dan proses perkuliahan.

Sertifikasi merupakan bentuk peningkatan dan pengakuan kompetensi guru pada bidang mata pelajaran tertentu yang ditempuh melalui jalur pemberkasan dan PLPG. Guru sertifikasi diatur dalam Undang-undang Nomor 14 Tahun 2005mengatur mekanisme sertifikasi bagi guru dan dosen. Pasal 8 UU guru dan dosen menyebutkan bahwa guru wajib memiliki kualifikasi akademik, kompetensi, sertifikat pendidik, sehat jasmani, rohani, dan memiliki kemampuan mewujudkan tujuan pendidikan nasional. Diperoleh data bahwa sertifikasi baru mampu meningkatkan tingkat kesejahteraan guru, namun belum meningkatkan kualitas profesi guru (Imanuel Sri Murdadi; 2015).

Sertifikasi melalui PLPG menghsilkan kemampuan profesi guru yang tersertifikasi lebih baik, namun berdasarkan hasil wawancara dengan beberapa guru, diperoleh keterangan bahwa PLPG belum mampu mengakomodir seluruh permasalahan yang dihadapi oleh guru dalam menjalankan kegiatan pembelajaran biologi, baik secara konten maupun pedagogi. Oleh karena itu guru-guru yang telah maupun belum disertifikasi diarahkan untuk saling berbagai kompetensi melalui wadah MGMP/KKM di wilayahnya masingmasing.
MGMP berdampak positif terhadap peningkatan kompetensi profesional guru (Rian Anggara;2012). MGMP dan KKM diberdayakan oleh tiap kelompok kerja madrasah sebagai wadah bagi guru untuk saling bertukar pikiran dan peningkatan kemampuan profesi, pedagogi, dan social. Sehingga diharapkan melalui KKM/MGMP setiap guru akan memiliki peningkatan kompetensi. Namun deiperoleh data di lapangan bahwa peranan MGMP/KKM belum maksimal, dikarenakan banyaknya kegiatan dan pemenuhan kewajiban administrative bagi guru, sehingga tidak semua guru mau dan mamp memberdayakan KKM/MGMP sebagai wadah untuk peningkatan kompetensi guru.

Pemerintah melalui kementerian terkain melakukan Pergantian kurikulum secara berkala. Guru diberikan diklat-diklat untuk mampu menguasai kurikulum yang baru, namun kenyataannya di lapangan banyak guru yang belum siap menerima dan melaksanakan kurikulum baru, hal ini berdampak pada proses KBM yang dilaksanakan terserah pada kompetensi guru yang bersangkutan. Keikut sertaan guru pada diklat-diklat terbatas, hal ini ditambah dengan fasilitas laboratorium yang tidak dimiliki atau dibawah standar oleh sekolah-sekolah, sehingga pelaksanaan kurikulum baru semacam dipaksakan tanpa adanya penyeimbangan dalam sarana dan prasarana. Pada beberapa kasus Kampus UIN yang memiliki Fakults tarbiyah dan keguruan (FTK) mellaui prodi pendidikan biologi melaksanakan pengabdian masyarakan secara berkala dalam upaya peningkatan kompetensi guru biologi, namun tidak berjalan escara continue dikareakan padatnya aktivitas di Madrasah.

Kmapus sebagai wadah penghasil calon guru memiliki kepentingan untuk memperoleh umpan baik berupa gambaran 
kualitas lulusan dari stakeholder melalui penjaringan data lulusan. Hal ini dilakukan bukan hanya sebagai data penunjang akreditasi, namun lebih pada perbaikan proses perkuliahan, karena melalui penjaringan umpan balik dari alumni dan stakeholder akan diperoleh gambaran kesulitan apa saja yang dihadapi oleh alumni, sehingga pada akhirnya akan dilakukan perbaikan pada perkuliahan (mata kuliah tertentu yang dilaksanakan selama perkuliahan dan di lapangan para lulusan kurang menguasainya atau memerlukan inovasi)

Fakta hasil UN tahun 2017, yang menunjukkan bahwa hasil UN terutama pelajaran Biologi jauh di bawah dibandingkan dengan sekolah-sekolah umum, walaupun secara keseluruhan hasil UNBK secara nasional memang megalami penurunan. Oleh Karen aitu penting digali permasalahan-permsalahn di lapangan yang dihadapi guru dalam pemalksanakan KBM.

Berbagai bentuk kebijakan pemerintah tersebut ditujukan untuk meningkatkan professional guru. Adapun profesional adalah pekerjaan atau kegiatan yang dilakukan seseorang dan menjadi sumber penghasilan kehidupan yang memerlukan keahlian, kemahiran, atau kecakapan yang memenuhi standar mutu atau norma tertentu, serta memerlukan pendidikan profesi.

Diberlakukannya kurikulum 2013 merupakan tantangan tersendiri bagi setiap guru. Khususnya guru biologi, setelah kurang lebih 25 tahun melaksanakan fungsi profesi sebagai guru. Penulis tersadarkan kembali akan hakikat sains yaitu keterampilan proses, hal ini sejalan dengan tuntutan kurikulum 2013, yang menuntut proses pembelajaran melalui tahapan $5 \mathrm{M}$ (Mengamati, Menanya, Mengobservasi, mengasosiasi, dan mengkomunikasikan). Namun demikian setelah begit lama profesi ini dijalani, tidak jarang cara mengajar kembali pada semula yaitu ceramah, dan pemberian contoh dan atau carata ditambah video yang ternyata malah menina bobokan peserta didik dalam proses pembelajaran.

Dalam proses pembelajaran, sebagaimana termaktub dalam Undang-undang Nomor 14 Tahun 2005 tentang Guru dan Dosen Pasal 20 Poin a, disebutkan bahwa: Tugas keprofesionalan guru adalah: merencanakan pembelajaran, melaksanakan proses pembelajaran yang bermutu, dan (3) melaksanakan evaluasi pembelajaran. Ketiga indikator pembelajaran itu harus dilaksanakan secara optimal oleh guru guna mencapai tujuan pembelajaran yang telah ditetapkan. Oleh karena itu, sebagaimana diamanatkan Undang-undang tersebut, pada poin $b$ ditegaskan bahwa guru harus meningkatkan dan mengembangkan kualifikasi akademik dan kompetensi secara berkelanjutan sejalan dengan perkembangan ilmu pengetahuan, teknologi, dan seni.

Proses pembelajaran merupakan inti dari proses pendidikan yang di dalamnya terdapat serangkaian hubungan timbal balik yang bersifat edukatif antara guru dengan siswa. Interaksi edukatif tersebut dapat dilaksanakan secara optimal apabila guru memahami dan melaksanakan dengan baik komponen-komponen pembelajaran, baik perencanaan, pelaksanaan, dan pengevaluasian pembelajaran.

Biologi merupakan wahana untuk meningkatkan pengetahuan, keterampilan, sikap, dan nilai. Biologi juga merupakan wadah untuk membangun warga negara yang memperhatikan lingkungan serta bertanggungjawab kepada masyarakat, bangsa, dan negara disamping beriman dan bertakwa kepada Tuhan Yang Maha Esa. 
Biologi berkaitan dengan cara mencari tahu dan memahami alam secara sistematis, sehingga biologi bukan hanya penguasaan kumpulan pengetahuan yang berupa fakta-fakta, konsep-konsep, prinsipprinsip saja tetapi juga merupakan suatu proses penemuan. Pendidikan Biologi diharapkan dapat menjadi wahana bagi siswa untuk mempelajari dirinya sendiri dan alam sekitarnya.

Pendidikan Biologi menekankan pada pemberian pengalaman secara langsung. Karena itu, siswa perlu dibantu untuk mengembangkan sejumlah keterampilan proses supaya mereka mampu menjelajahi dan memahami alam sekitar. Keterampilan proses ini meliputi keterampilan mengamati dengan seluruh indera, mengajukan hipotesis, menggunakan alat dan bahan secara benar dengan selalu mempertimbangkan keselamatan kerja, mengajukan pertanyaan, menggolongkan, menafsirkan data dan mengkomunikasikan hasil temuan secara beragam, menggali dan memilah informasi faktual yang relevan untuk menguji gagasan-gagasan atau memecahkan masalah sehari-hari.

Standar kompetensi kurikulum yang diterbitkan KEMENDIKUBUD menyatakan bahwa fungsi dan tujuan mata pelajaran biologi. Mata Pelajaran Biologi berfungsi untuk menanamkan kesadaran terhadap keindahan dan keteraturan alam sehingga siswa dapat meningkatkan keyakinan terhadap Tuhan Yang Maha Esa sebagai warga negara yang menguasai sains dan teknologi untuk meningkatkan mutu kehidupan dan melanjutkan pendidikan. Mata Pelajaran Biologi bertujuan untuk:

1. Memahami konsep-konsep biologi dan saling keterkaitannya.

2. Mengembangkan keterampilan dasar Biologi untuk menumbuhkan nilai serta sikap ilmiah.

3. Menerapkan konsep dan prinsip Biologi untuk menghasilkan karya teknologi sederhana ang berkaitan dengan kebutuhan manusia.

4. Mengembangkan kepekaan nalar untuk memecahkan masalah yang berkaitan dengan proses kehidupan dalam kejadian sehari-hari.

5. Meningkatkan kesadaran akan kelestarian lingkungan.

6. Memberikan bekal pengetahuan dasar untuk melanjutkan pendidikan.

Dalam melaksanakan pembelajaran akan terlihat pada kemampuan melaksanakan langkah-langkah pembelajaran; baik pada kegiatan awal, inti, dan akhir pembelajaran. Kegiatan-kegiatan dalam pembelajaran itu akan terlihat dari model, pendekatan, dan metode pembelajaran serta sumber, alat, dan sarana pembelajaran yang diterapkan dan digunakan.

Berbagai permasalahan diatas belum diperoleh data detail tentang dominasi permasalaan apa saja yang dihadapi oleh guru dalam pelaksanaan KBM, dalam hal ini pembelajaran Biologi. Oleh karena itu penting dilaksanakan penjaringan data konkrit yang melatarbelakangi permasalah tersebut, sehingga kesulitan-kesulitan yang dihadapi oleh guru biologi di lapangan dapat dijadikan masukkan bagi perbaikan proses peningkatan kualifikasi guru dalam melaksanakan tugas professional nya.

\section{METODE PENELITIAN}

Penelitian ini menggunakan metode penelitian kualitatif, metode pengumpulan data menggunakan observasi, wawancara, dan dokumentasi. Prosedur analisis data adalah pengumpulan data, reduksi data, penyajian data, dan penarikan kesimpulan

Variabel pada penelitian ini adalah kesulitan guru dalam melaksanakan pembelajaran biologi di Provinsi Jawa Barat (study kasus priyangan Timur) sebagai variabel tunggal. Pada penelitian ini yang menjadi populasinya adalah 
seluruh guru Biologi se-provinsi Jawa Barat yaitu guru madrasah Tsanawiyah (MTs), Madrasah Aliyah (MA) dan guru Biologi SMP/SMA. Sampel yang digunakan dalam penelitian ini adalah 109 guru biologi yang berada di wilayah priyangan timur (Ciamis termasuk Banjar \& Pangandaran, Tasikmalaya, Garut, Sumedang, Cimahi, Bandung, Cianjur, Sukabumi dan Bogor). Dari masingmasing kabupaten dan kota akan diambil sampel Madrasah masing-masing dua sekolah Negeri dan 2 sekolah Swasta secara acak. Setelah ditetapkan nama sekolah secara acak, kemudian dipilih guru biologi sebagai objek dalam penelitian ini secara acak. Selain itu ditetapkan 5 orang siswa untuk setiap responden guru, untuk memberikan penilaian terhadap kinerja guru, dengan pertimbangan guru-guru pada wilayah tersebut merupakan guru yang berada di wilayah dengan keberadaan perguruan tinggi Negeri dan swasta yang berualitas.

Teknik pengumpulan data yang digunakan dalam penelitian ini pengisian angket, wawancara, dokumentasi dan observasi.Teknik wawancara digunakan untuk memperoleh data yang lebih rinci dan je-las mengenai kesulitan yang dialami guru biologi dalam melaksanakan proses kegiatan pembelajaran biologi di sekolah. Wawancara akan dilakukan pada guru biologi. Kemudian teknik dokumentasi peneliti gunakan untuk mendapatkan data dan informasi mengenai data konkrit factor permasalahan yang timbul dan dihadapi oleh guru biologi di sekolah dan atau wilayah masing-masing. Se-lanjutnya teknik observasi peneliti lakukan dengan menggunakan skala Guttman. Penelitian menggunakan skala Guttman dilakukan untuk mendapatkan informasi yang jelas dengan Ya (1) atau Tidak (0) dalam bentuk checklist, (Su-giyono,2011:139). Hal ini peneliti gunakan untuk mendapatkan informasi mengenai kegiatan yang dilakukan guru dalam melaksanakan kegiatan embelajaran biologi.

Data yang sudah terkumpul dianalisis dengan menggunakan analisis data teknik analisis data deskriptif kualitatif. Sugiyono (2009:246) menyatakan bahwa "Analisis data dalam penelitian kualitatif, dilakukan pada saat pengumpulan data berlangsung, dan setelah selesai pengumpulan data dalam periode tertentu". Miles dan Hubberman (1992:20) menyatakan bahwa „,Analisis data kualitatif merupakan upaya yang berlanjut, berulang-ulang dan terusmenerus". Sedangkan menurut Arikunto (2002:213) ,„Analisis data deskriptif kualitatif digambarkan dengan kata-kata atau kalimat dipisah-pisah menurut kategori untuk mendapatkan kesimpulan". Berdasarkan proses analisis data mengguna-kan teori Miles dan Huberman di atas, analisa data kualitatif meliputi tiga tahap analisis yaitu reduksi data, penyajian data, penarikan kesim-pulan/verifikasi.

\section{HASIL DAN PEMBAHASAN}

Berdasarkan hasil observasi diperoleh data kesulitan guru dalama pembelajaran biologi serta berbagai penunjangnya sebagai berikut.

a. Kesulitan Guru pada kompetensi Profesional

Terdapat 6 dari 26 konsep yang dianggap sulit baik oleh guru maupun siswa dalam pembelajaran biologi, adapun persentase dapat dilihat pada grafik berikut ini. 


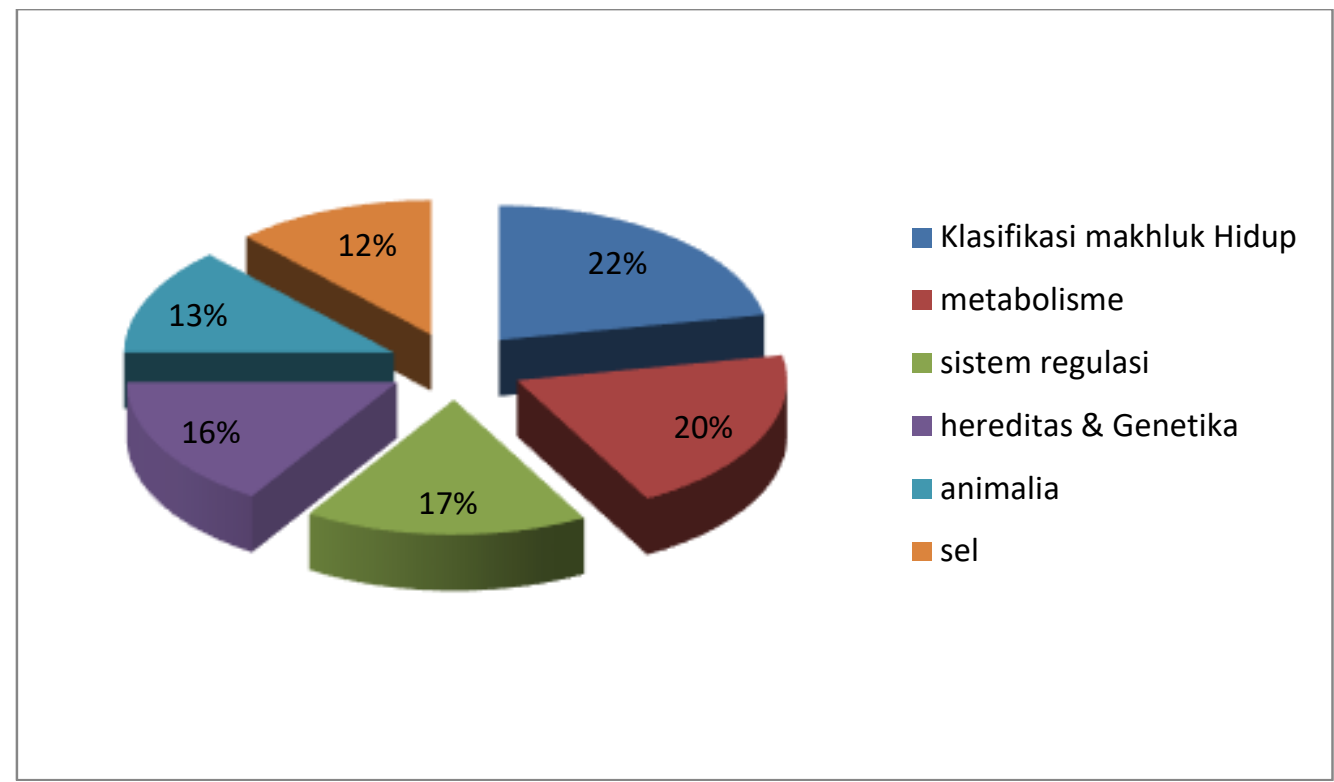

Gambar 1. Grafik kesulitan guru dan siswa pada konsep Biologi kesulitan yang dialami guru dalam pembelajaran biologi. Adapaun

b. Kompetensi pedagogic

Kompetensi pedagogic kompetensi pedagogic dapat dilihat berkontribusi besar terhadap pada grafik berikut ini.

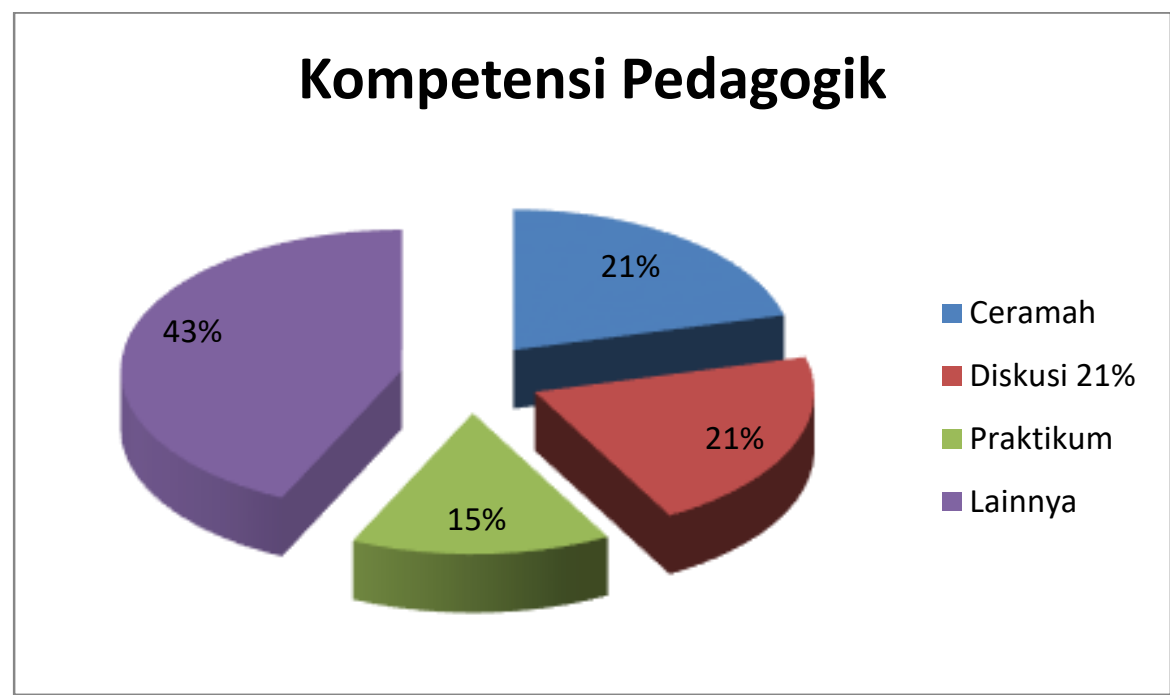

Gambar 2. Grafik penggunaan Kompetensi Pedagogik dalam Pembelajaran Biologi Adapun penggunaan media dalam pembelajaran elektronik dan pembelajaran biologi terbagi tradisional. Adapun persentasenya menjadi dua bentuuk yaitu meia dapat dilihat pada grafik berikut ini. 


\section{Penggunaan media pembelajaran oleh Guru Biologi}

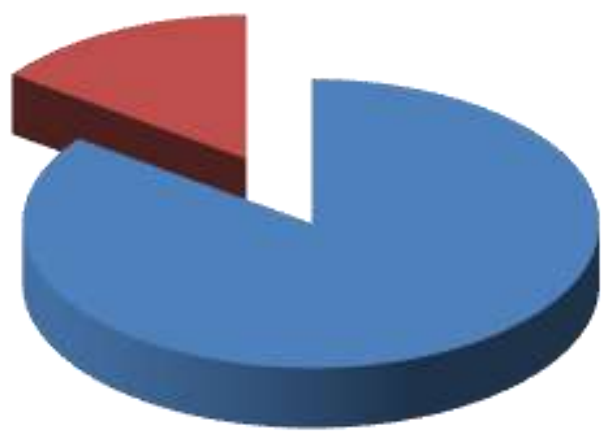

- LCD, PPT, Elektronik,

- Tradisional

Gambar 3. Penggunaan media pembelajaran oleh Guru Biologi

dan seberapa aktif guru tersebut dalam mengikuti peningkatan

Adapun kendala lain yang kualitas profesi melalui kegiatanberpengaruh terhadap tingkat perofesionalisme guru dalam pembelajaran biologi, juga dipengaruhi oleh gelar akademik kegiatan keprofesian seperti MGMP, Diklat, dan lainnya. Berikut adalah hasil observasinya.

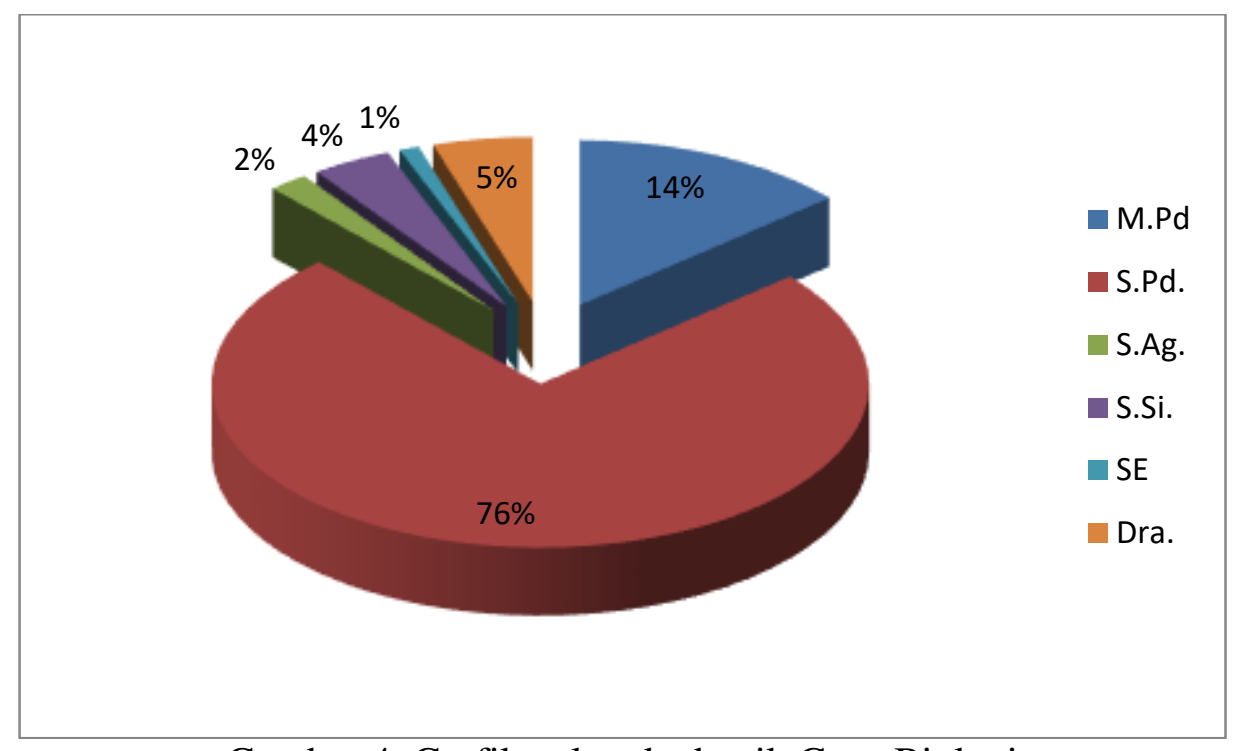

Gambar 4. Grafik gelar akademik Guru Biologi 


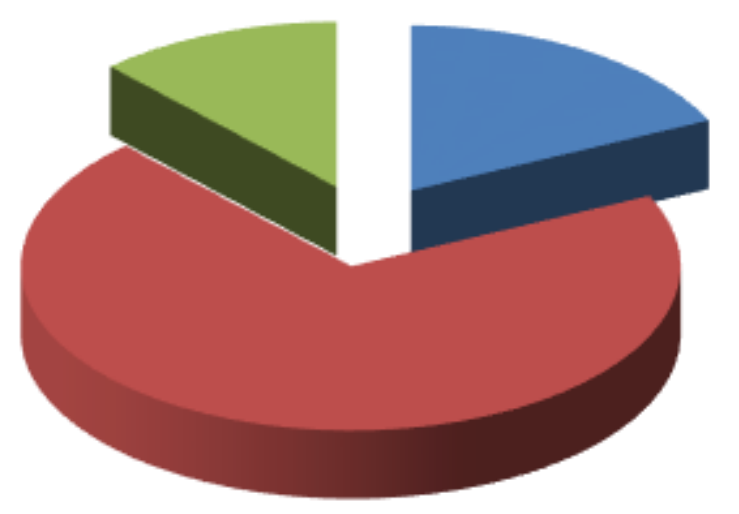

nelum Pernah

- Pernah

Sering

\section{Gambar 5. Grafik Aktivitas Peningkatan Kualitas Profesi Guru Biologi}

Berdasarkan data hasil penelitian di atas, terlihat bahwa dari 109 guru yang diobservasi di wilayah Provinsi Jawa Barat khususnya wilayah Priangan masih memiliki berbagai permasalah yang berdampak pada kesulitan guru dalam melaksanakan tugas profesinya sebagai pendidik terutama dalam pembelajaran biologi.

Bila merujuk pada tuntutan UUD tentang 4 dasar kompetensi guru, terlihat bahwa hal yang mendominasi adalah kesulitan guru dalam kompetnsi professional dan kompetensi pedagogic. Kompetensi pedagogic dan professional dipengaruhi besar oleh kondisi sarana Laboratorium yang rata-rata belum memadai secara optimal, sehingga guru kesulitan unutk menyampaikan konsepkonsep biologi yang abstrak. Dari segi kompetensi social guru dihadapkan pada peribahan gaya hidup, dimana siswa lebih terpengaruhh dengan gadget dan media dunia maya lainnya, sehingga guru seringkali kalah bersaing dengan siswa.
Berbagai permasalahn yang dihadapi guru Biologi dalam pembelajaran, aganya perlu mendapatkan perhatian dari berbagai pihak, sehingga berbagai kebijakan terkait peningkatan kompetensi guru lebih tepat saran sesuai kebutuhan dan permasalahan dilapangan, pun demikian dengan kebijakan perubahan kurikulum yang bberapa kali diganti dalam jeda waktu yang berdekatan hendaknya mempertimbangkan kesiapan guru sebagai ujung tombak pelaksana dari kurikulum yang diberlakukan.

\section{KESIMPULAN}

Berdasarkan hasil penelitian, diperoleh data kesulitan guru dalam pembelajaran biologi di wilayah provinsi Jawa Barat (study kasus priyangan) bahwa kesulitan guru dalam melaksanakan pembelajaran Biologi terbagi menjadi dua; 1). Internal, pada kompetensi professional terdapat 6 materi yang dianggap sulit oleh pendidik maupun siswa yaitu sistem klasifikasi makhluk hidup 22\%, metabolisme $20 \%$, system regulasi $17 \%$, heredias dan genetik 16\%, animalia 13\%, dan Sel 12\%; kompetensi pedagogic, guru menggunakan 18 metode pembelajaran dengan dominasi $21 \%$ ceramah, $15 \%$ Praktikum, dan $21 \%$ diskusi, sisanya bervariasi, namun dalam penggunaan 
media $85 \%$ sudah berbasis media elektronik dan 15\% masih tradisional. 2). Eksternal, yaitu tidak sesuainya kurikulum yang diberlakukan pada madrasah/sekolah dengan fasilitas kelas dan Laboratorium, kebijakan madrasah yang berbeda-beda, beragamnya peningkatan kompetensi yang telah diikuti guru biologi. Adapun persentase kesulitan dalam pemelajaran Biologi secara umum ditemui $48 \%$ dari sudut pandang siswa, $10 \%$ Guru, dan $41 \%$ sarana dan prasarana. Berbagai kendala tersebut didukung oleh aktifitas peningkatan kompetensi profesi seperti MGMP, Diklat dll yang telah diikuti oleh guru yaitu; $18 \%$ belum pernah, $70 \%$ pernah, dan $12 \%$ sering. Dari segi gelar akademik, 85 guru yang dijadikan sumber data memiliki gelar akademik $76 \%$ S.Pd, 14\% M.Pd, 2\% S.Ag, 2\%S.Si, 5\% Dra, dan $1 \%$ SE. Hasil analisis data kesulitan yang dihadapi guru dalam pembelajaran biologi di provinsi Jawa Barat (studi kasus Priangan) diharapkan dapat menjadi referensi dasar dalam penetapan kebijakan dan usaha peningkatan SDM maupun Output pada madrasah/sekolah kementerian terkait.

\section{UCAPAN TERIMA KASIH}

Kegiatan penelitian ini didukung oleh Pusat Penelitian dan Penerbitan (LP2M), UIN Sunan Gunung Djati Bandung melalui Pendanaan BOPTN DIPA UIN Sunan Gunung Djati Bandung 2018. Ucapan terimakasih disampakan kepada Ibu Ade Yeti Nuryantini yang telah sudi menjadi reviewer dalam penelitian ini.

\section{DAFTAR PUSTAKA}

Firman. (2010). Peranan MGMP Dalam Meningkatkan Kinerja Guru Mata Pelajaran Pendidikan Agama Islam SMA di Kota Balikpapan. Fakultas Keguruan dan Ilmu Pendidikan. Universitas Balikpapan.

Imanuel Sri Murdadi \& Entri Sulistari. (2015). Dampak sertifikasi guru dalam peningkatan kompetensi Profesional di kalangan guru smk pelita salatiga. Prosiding Seminar Nasional 9 Mei 2015, 650-662. Salatiga
Mohammad Zulkifli, dkk. (2014). Motivasi Kerja, Sertifikasi, Kesejahteraan Dan Kinerja Guru. Persona, Jurnal Psikologi Indonesia Persona, Jurnal Psikologi Indonesia.

Nurhattati Fuad. (...) Pengaruh Sertifikasi Guru Terhadap Peningkatan Kinerja Guru PAI di SMP dan MTs . Program Studi Manajemen Pendidikan UNJ.

Permendikbud RI No. 65. (2013). Standar Proses Pendidikan Dasar dan Menengah. Kemendikbud.

Rian Anggara dan Umi Chotimah. (2012). Penerapan Lesson Study Berbasis Musyawarah Guru Mata Pelajaran (Mgmp) Terhadap Peningkatan Kompetensi Profesional Guru Pkn Smp Se-Kabupaten Ogan Ilir. Jurnal Forum Sosial, 5 (2) 188-197.

Rian Anggara, dkk. (2012). Penerapan lesson study berbasis musyawarah guru mata pelajaran (MGMP) terhadap peningkatan kompetensi profesional guru Pkn SMP se-kabupaten Ogan Ilir. FKIP Universitas Sriwijaya.

Soebagyo Brotosedjati. (2012). Kinerja guru yang telah lulus sertifikasi guru dalam jabatan. JMP. 1 (2) 189-199.

Terry Irenewaty. (2015). kesulitankesulitan guru dalam implementasi ktsp mata pelajaran sejarah sekolah menengah atas (penelitian di sma $\mathrm{n}$ i prambanan klaten). UNY. 10(2) 103117.

Undang-undang Nomor 14 Tahun 2005, Guru dan Dosen. Diknas: Jakarta.

Zikrika. (2015). Efektifitas penggunaan Laboratorium IPA dalam pembelajaran biologi di SMPn 3 Palembang. Skripsi UIN Raden Fatah Palembang. 